\title{
REFLECTIONS OF NUMBER SYMBOLISM ON EGYPTIAN SACRED ARCHITECTURE
}

\author{
Zeinab Feisal Abdel Kader \\ Faculty of Engineering, MTI University
}

\begin{abstract}
Numbers have long been seen as expressions of cosmic order, possibly deriving from ancient Babylonian observation of regular cosmic events, such as night and day, the phases of the moon and cycles of the year.
\end{abstract}

Belief architecture Filled with symbolism for the reason of its indirect impact on the spiritual atmosphere of this type of buildings. Symbolism can be found in which symbolic colors, symbolic shapes, number symbolism and other symbolic tools that emphasize on the spatial experience of these buildings. The research deals with number symbolism in religious buildings in Egypt and their meaning. This study extends along three periods of Egyptian architecture; that represent Ancient Egyptian Architecture, Coptic Architecture and Islamic Architecture in Egypt.

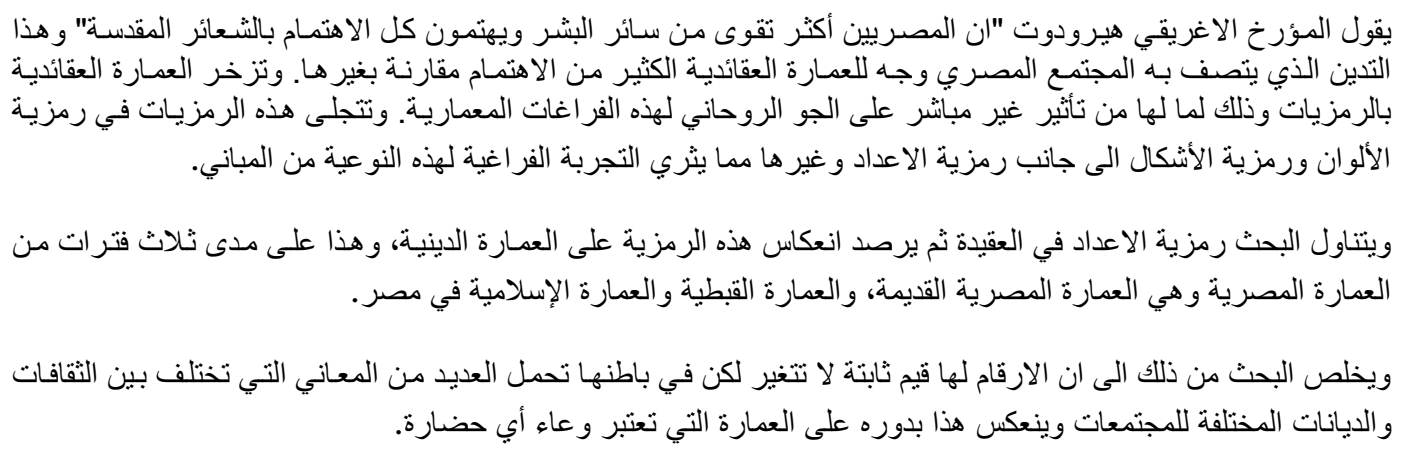

Keywords: Sacred Architecture, symbolism, number symbolism, Ancient Egyptian, Coptic Architecture and Islamic Architecture. 


\section{Symbolism:}

Symbols represent something other than what they actually are. Generally, they are based on conventionally agreed upon meanings, but unlike signs, which usually stand for something very concrete (as in the case of mathematical signs), symbols usually stand for something less visible or tangible than the symbol itself. As an example, we have many symbols today, such as the cross for Christianity, the half-moon for Islam.

\section{Number symbolism:}

In many cultures numbers are full of symbolic meaning and in some culture numerology have an influence on the future .

Viewed symbolically, numbers represent more than quantities, they also have qualities. To the Greek mathematician Pythagoras, Even Numbers were Feminine, divisible into two equal parts and passive, Odd Numbers were masculine and active (Bruce, 2004).

\section{Number symbolism in Ancient Egyptian sacred architecture:}

When attempting to understand the ancient Egyptians and their culture, some understanding of symbolism and how it affected the ancient Egyptians is essential.

In fact, as one stands before the Great Pyramids of Giza, there is layer upon layer of symbolism. These pyramids are symbolic of man's ancient triumphs, but to the ancient Egyptians, they symbolized the very fabric of creation; the primordial mound from which life arose. The same for the famous temples and tombs are symbols that had great meaning to the ancient Egyptians.

The civilization of ancient Egypt was symbolically oriented to a degree rarely equaled by other cultures. It was through symbols that the Egyptians represented and affirmed many of their ideas, beliefs and attitudes regarding the nature of life, death, the supernatural and reality. Symbols often depict aspects of reality or ideas that are difficult to represent through other modes of expression, and the ancient Egyptians used them constantly in this manner. Several numbers held symbolic significance for Ancient Egyptians and numbers have played symbolic roles in Egyptian sacred architecture.

\subsection{Number One in Ancient Egyptian:}

Number One symbolizes "Atum" that was the first and most important Ancient Egyptian god to be worshiped.

In the beginning there was nothing (Nun); a mound of earth rose from Nun and upon it Atum created himself (Bruno, 2006).

Atum was the father of the gods, creating the first divine couple, Shu and Tefnut, from whom all the other gods are descended. He was also considered to be the father of the Pharaohs. Many Pharaohs used the title "Son of Atum"

Atum is most usually shown wearing the dual crown of Upper and Lower Egypt.

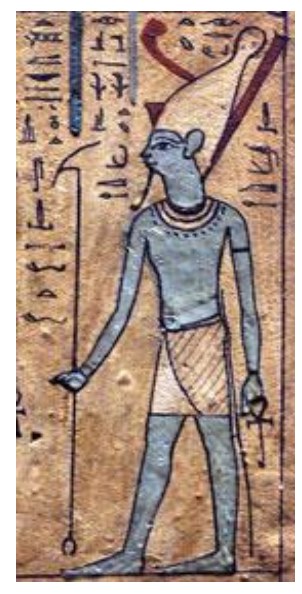

Fig.1 Atum (Tempel interior wallRelief)

One of the only details that distinguish him from a Pharaoh is the shape of his beard. He is also depicted with a solar disk and a long tripartite wig .

\subsection{Number two in Ancient Egyptian:}

The phenomenon of duality pervades Egyptian culture and is at the heart of the Egyptian concept of the universe, which views the many evident dichotomies of light and dark, sun and moon, east and west, stability and chaos and so on, as expressions of the essential unity of existence.

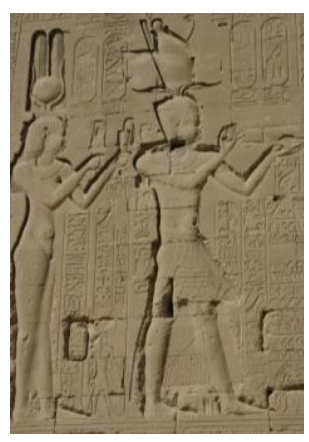

Fig.2 Kingship and divinity, Denderah temple، Cleopatra (Isis crown) Cesarion (Amun crown)

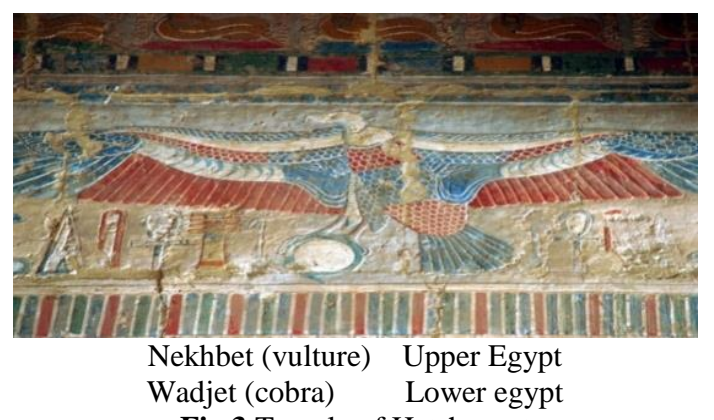

Fig.3 Temple of Hatshepsut 


\subsection{Number three in Ancient Egyptian:}

The Egyptians symbolized 3 as being heavenly due to the triads of gods. While three was the number associated with the concept of plurality, three was also a number of unity inherent in plurality, as may be seen in the many divine families which Egyptian theology constructed of a god, his wife and their child, or in the characterization of Amun, Re and Ptah as the soul, face and body of the god.

The most popular triads were:

Osiris -- Isis -- Horus

Amun -- Mut -- Khonsua

\section{A group of three stars called Orion's Belt:}

Another odd fact, which is a favorite of conspiracy theorists, is that the Egyptian pyramids at Giza seem to line up with a group of stars called Orion's Belt; this idea is known as the Orion Correlation Theory (Bauval, 2010). Many Egyptologists have tried to explain the correlation but the orthodox ones have ignored and dismissed many claims. According to sky planetarium programs, the only time the pyramids were aligned with Orion's Belt was in 10 $000 \mathrm{BC}$. According to archaeologists, it would have been impossible for the Egyptian civilization being around at that time as there is no evidence. Some still maintain that this idea is correct and might very well be.

\section{Fig. 4}

The orientation and size of the pyramids of Giza in Egypt look quite similar to Orion's Belt.

(Up)

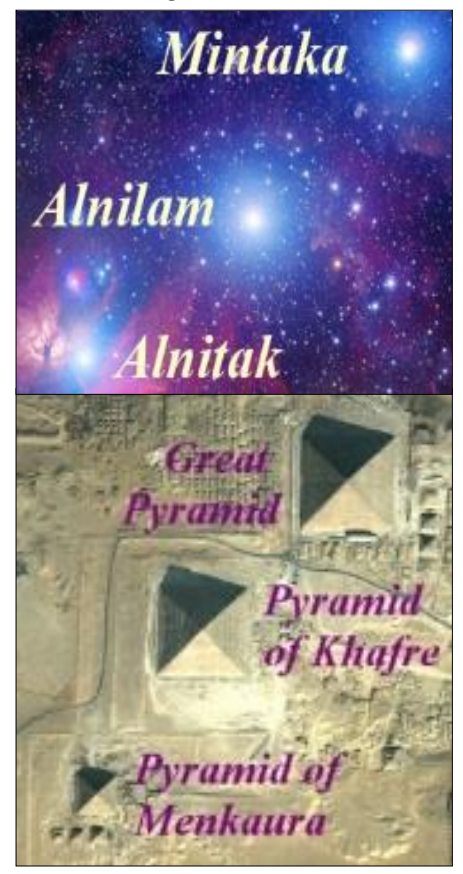

Orion's Belt

(Down)

Giza Pyramids

\subsection{Number four in Ancient Egyptian:}

The Egyptians symbolized 4 as the essence of physicality and earthiness due to the world being created of: air "Shu", moisture "Tefnut", sky "Nut" and earth "Geb".

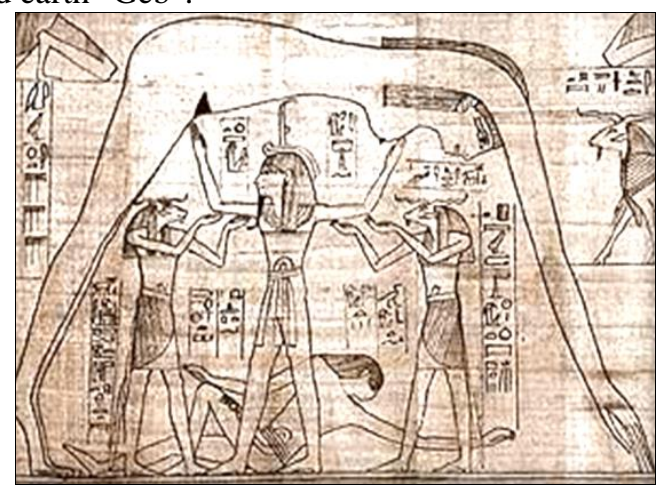

Fig.5 Shu, Tefnut, Nut and Geb

\section{Four Canopic jars:}

These are four vessels in which the viscera extracted fromthe dead body were preserved; each jar was under the protection of one of the four sons of Horus، whose names were Imset, Hapy, Duamutef, and Kebehsenuf (Cerny, 1952).

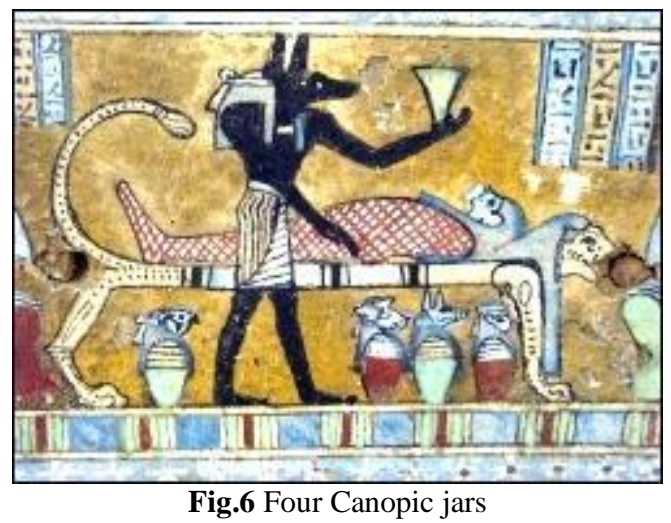

Once they were cleansed, the liver, intestines, stomach, and lungs were packed with natron into four special vessels called canopic jars. Canopic jars could be made of anything from pottery and limestone to more precious materials such as alabaster or even gold. There were specific jars for each of the four organs, and their look and religious function evolved over time (Rawlinson, 2009).

\subsection{Number five in Ancient Egyptian:}

Ancient Egyptians symbolized 5 as universe where the gods live eternally because the pentagonal five pointed star aptly symbolizes the belief that the king, after his death, becomes a star (Lawlor, 2002). 


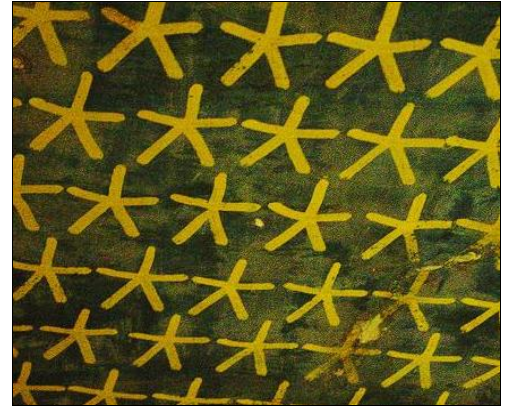

Fig.7 The tomb of the pharaoh, Thutmosis III. The blue ceiling dotted with bright yellow pentagonal five pointed stars.

The Ancient Egyptians believed there was a region in space called the Duat where the souls of dead pharaohs went. The symbol of this was the five pointed star. Also the constellation of Orion was used to represent the main Egyptian God, Osiris (Lehman, 2006).

It was believed that the stars did not just inhabit this world, but in the Duat (land of the afterlife) as well. The Egyptians believed that the Ba might ascend to the sky to live as a star in heaven. Many tombs also featured deep blue ceilings dotted with bright yellow stars in the exact image of the hieroglyph in hopes to make the ba feel at home in its new dwelling place. The stars were called the "Followers of Osiris and represented the souls in the underworld.

In Ancient Egypt, they believed that the human spirit was made up of five parts: The $\mathrm{Ib}$, Sheut, Ren, $\mathrm{Ba}$, and $\mathrm{Ka}$. Although all five were of importance, the $\mathrm{Ba}$ and $\mathrm{Ka}$ are of major significance (Ernest, 2010).

\subsection{Number seven in Ancient Egyptian:}

Hathor is one of the most famous goddesses of Ancient Egypt. She was known as "the Great One of Many Names" and her titles and attributes are so numerous that she was important in every area of the life and death of the ancient Egyptians

As the "lady of the west" and the "lady of the southern sycamore" she protected and assisted the dead on their final journey. Trees were not commonplace in ancient Egypt, and their shade was welcomed by the living and the dead alike. She was sometimes depicted as handing out water to the deceased from a sycamore tree (a role formerly associated with Amentet who was often described as the daughter of Hathor) and according to myth, she (or Isis) used the milk from the Sycamore tree to restore sight to Horus who had been blinded by Set. Because of her role in helping the dead, she often appears on sarcophagi with Nut (the former on top of the lid, the later under the lid).

She occasionally took the form of the "Seven Hathors" who were associated with fate and fortune telling. It was thought that the "Seven Hathors" knew the length of every child's life from the day it was born and questioned the dead souls as they travelled to the land of the dead. Her priests could read the fortune of a newborn child, and act as oracles to explain the dreams of the people. People would travel for miles to beseech the goddess for protection, assistance and inspiration (Pinch, 2004).

The "Seven Hathors" were worshiped in seven cities: Waset (Thebes), Iunu (On, Heliopolis), Aphroditopolis, Sinai, Momemphis, Herakleopolis, and Keset. They may have been linked to the constellations Pleiades.

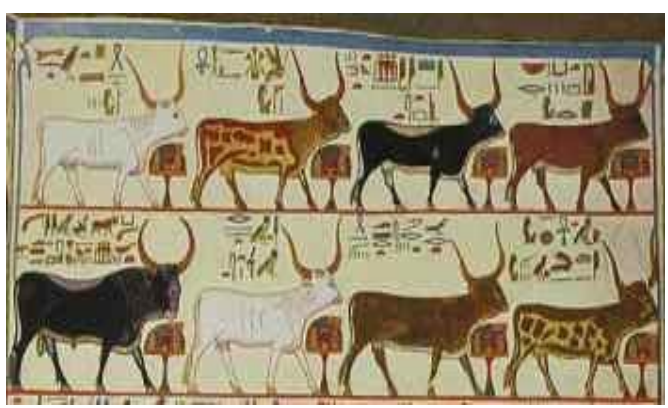

Fig.8 The Seven Hathors as cows accompanied by the bull of the west, lord of eternity,, tomb of queen Nefertari

\subsection{Number eight in Ancient Egyptian:}

An Ogdoad grouped 8 gods, 4 times a couple, each couple representing the male and female aspects of the elements that were present before creation (Pinch, 2004).

The Ogdoad are the eight deities worshipped in Hermopolis. The gods of the Ogdoad were mostly seen as humans with their animals' heads, or just depicted as snakes and frogs. They were arranged in four male-female pairs, with the males associated with frogs, and the females with snakes. Frogs are associated with biogenetic experiments. Snakes represent human DNA (Cerny, 1952).

The Egyptians believed that before the world was formed, there was a watery mass of dark, directionless chaos. In this chaos lived the Ogdoad of Khmunu (Hermopolis), four frog gods and four snake goddesses of chaos.

These deities were Nun and Naunet (water), Amun and Amaunet (invisibility), Heh and Hauhet (infinity) and Kek and Kauket (darkness). 

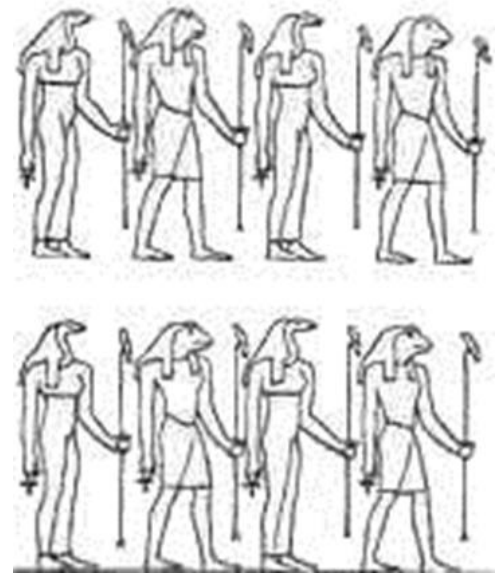

Fig.9 The Four Frog Gods and Four Snake Goddesses of the Ogdoad

The chaos existed without the light, and thus Kek and Kauket came to represent this darkness. They also symbolized obscurity, the kind of obscurity that went with darkness, and night .

\subsection{Number nine in Ancient Egyptian:}

A certain amount of order was brought to Egyptian mythology and its myriad of gods by the priests themselves. The result of this was the creation of a number of enneads, groups of nine gods and goddesses, usually organized into families. The number nine was a sacred and symbolic number that could also stand for 'all' gods. This was because the Egyptians indicated plurals by using three, and nine was thus perceived as the plural of plurals.

The most important ennead was that of Heliopolis, often called the Great Ennead. At its head was Atum, the creator and sun god. His children Shu and Tefnut gave birth to the earth god Geb and the sky goddess Nut, who in turn were the parents of Osiris, Isis, Nephthys and Seth. Occasionally Horus is added to them as a tenth god, sometimes as the fifth generation (child of Osiris and Isis) and sometimes as Nut's fifth child (Leonard, 1991).

\section{Number symbolism in Coptic Architecture:}

Although some references have classified Coptic art as a branch of Byzantine art which means neglect of the role of Coptic art, there are some elements of Christian art that were first produced by Copts. For example, the idea of the icon from the start was widespread in Egypt even before the beginning of Christian art was represented in the portraits of Fayoum and Akhmim and Copts were putting their pictures in their homes as it's happening now. This didn't exist in the Christian world at that time, then Copts created icons of Jesus Christ, Virgin Mary, Saint George, angel Michael and other icons that represent important events such as enter Jerusalem, and others (Seriany, 1995).
These religions that required extensive symbolism, because things like the nature of God and the Trinity are hard to explain in words but could be expressed symbolically (Shahinian, 1996).

\subsection{Number three in Coptic architecture:}

Is one of the most symbolic numbers for Christian Copts that it symbolizes the Christian triad of the Holy Trinity, Father, Son, and Holy Spirit.

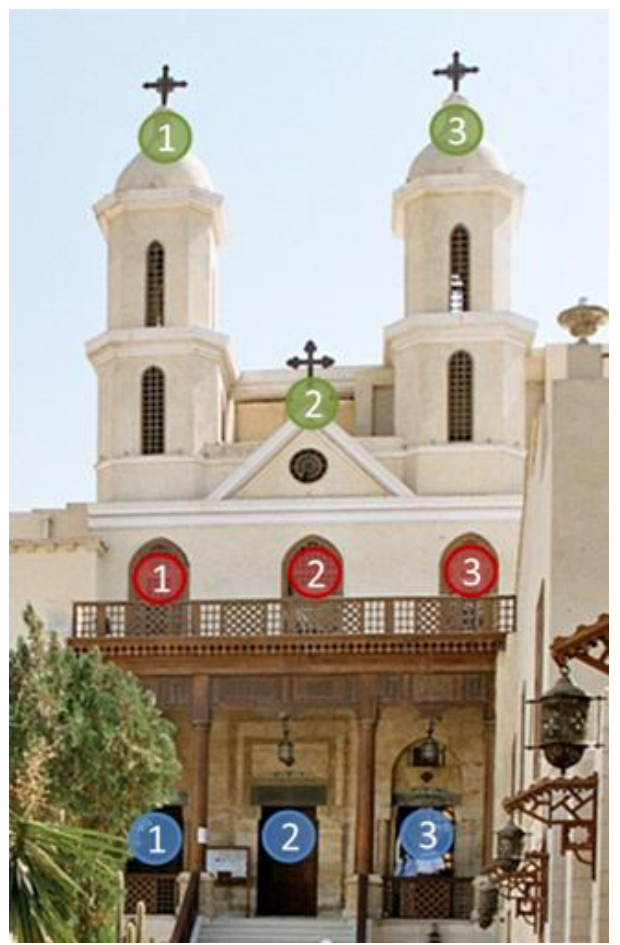

Fig.10 Hanging church Old Cairo Series of threes

\subsection{Number four in Coptic architecture:}

Number four can symbolize four Evangelists Matthew, Mark, Luke, and John. Three of them are often represented by animals; the ox for Luke, and the eagle for John, and the lion for Mark. Matthew is always represented as a man (Kamil, 2002).

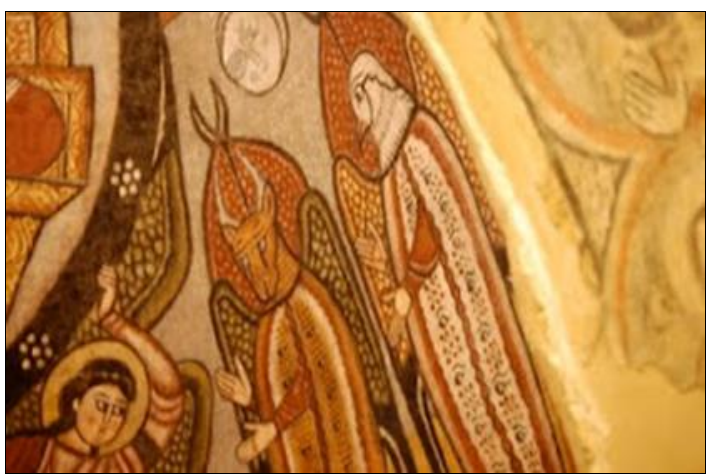

Fig.11 The Apostles St. Luke, St John, St Mathew and St. Mark in the Chapel of St. George at the Church of St. Mina Old Cairo. 
4.4 Number five in Coptic architecture:

Number five is associated with the number of letters the word fish in Greek. The fish was a symbol of Christ, representing the first letters of words "Jesus Christ Son of God, Savior" (Sill, 1976).

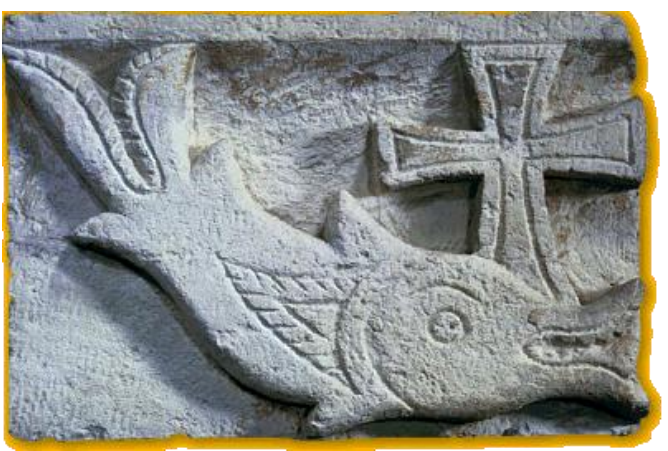

Fig.12 Fish in early Christian (Coptic) art Limestone, Egypt, 5th century B. C.)

4.5 Number seven in Coptic architecture:

The Christian life is ordered by series of seven (the seven capital sins, seven virtues, seven sacraments, etc. (Shahinian, 1996).

Behind the Altar and around the Eastern wall of the Sanctuary, lies the Tribune. This is often made of marble or stone, and consists of seven semi-circular steps. The steps represent the orders of Priesthood. Then the priests sitting on the stairs by their grades, this system exists in most churches in Old Cairo. Typical examples are present in the Church of St.Mina, in Mariut, and in the Churches of Babylon, in Old Cairo (the suspended Church of the Most Holy Virgin Mary, St. Sergius, St. Mercurius, and St. Barbara).

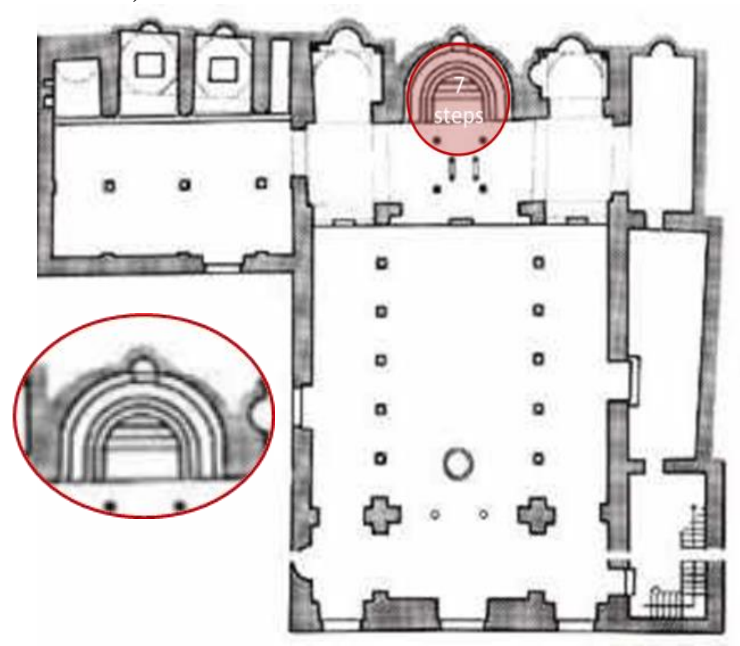

Fig.13 St. Barbara church Sanctuary has seven steps

\subsection{Number eight in Coptic architecture:}

Number Eight is the first number after seven. It is the symbol of life, the new life after baptism. In early Christian belief, the resurrection of Christ happens on the eighth day and the reason of that the octagon is the favored form for the Baptisteries.

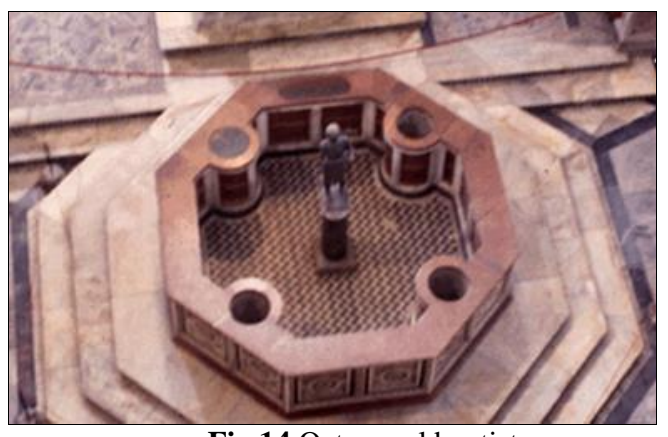

Fig.14 Octagonal baptistery

Eight and the octagon represent resurrection and rebirth, because Christ rose from grave 8 days after entry into Jerusalem. Thus they became symbols of baptism, the spiritual rebirth of a person, and many baptisteries and baptismal fonts are octagonal.

\subsection{Number twelve in Coptic architecture:}

In Christianity: the twelve apostles, the twelve stars around the head of the apocalyptic woman, ect. (Shahinian, 1996).

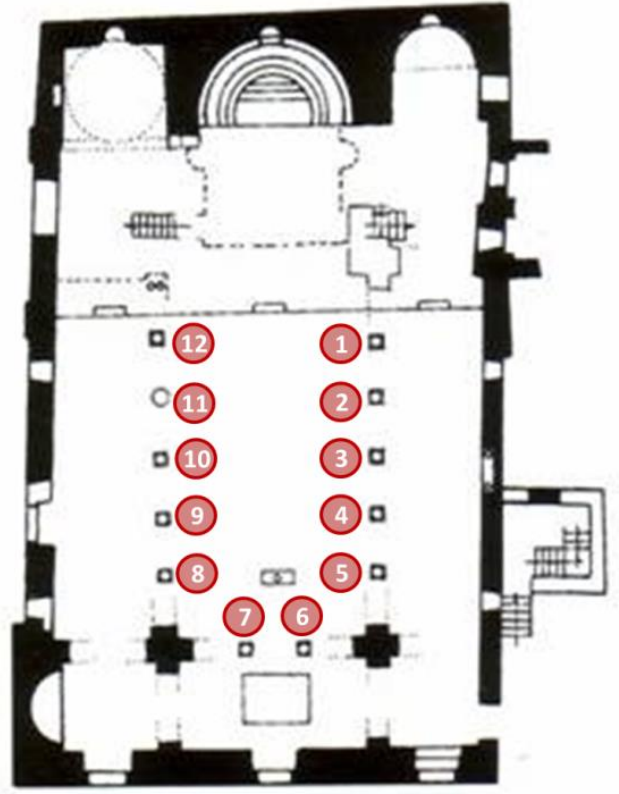

Fig.15. St. Sergius Church, Old Cairo

Church nave has twelve columns to symbolize the twelve apostles

4.8 Number thirteen in Coptic architecture: Sometimes number thirteen symbolizes the number of the twelve apostles plus Jesus. 


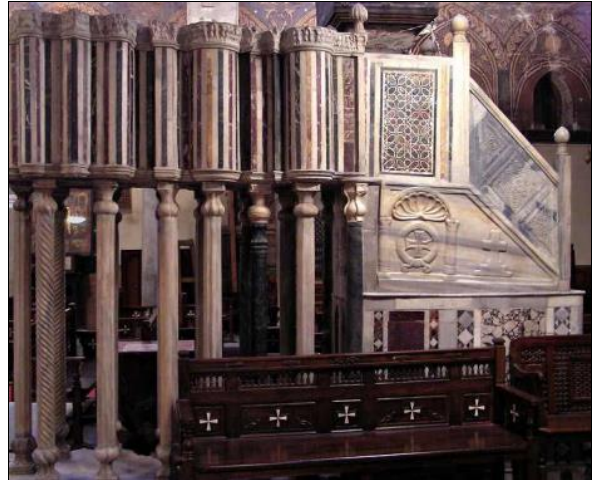

Fig.16. Hanging church, Old Cairo Tribune with 13 columns

\section{Number symbolism in Islamic architecture:}

Islamic architecture in Egypt went through several periods and each period has its features. During these periods, religious beliefs were the greatest factors that form this architecture. The religious doctrine prevailing in Egypt, Sunni Islam until the arrival of the Fatimid state became the prevailing doctrine is the Shiite sect that was the Ayyubid period to restore the Sunni sect once again to be the official doctrine. Sometimes There is different symbolic meaning of some numbers in the Islamic architecture buildings according to the doctrine prevailing in the period in which the construction of the building. That is why the research offers some symbolic numbers in Islamic religious architecture.

5.1 Number One in Islamic architecture: Islamic religion depends on unity. Number one refers to one God to unity act the Absolute; self-sufficient.

\subsection{Number four in Islamic architecture:}

The Qur'an has many references to paradise "Jannah" and its description. There are four rivers in Paradise, filled with milk, honey, wine and water.

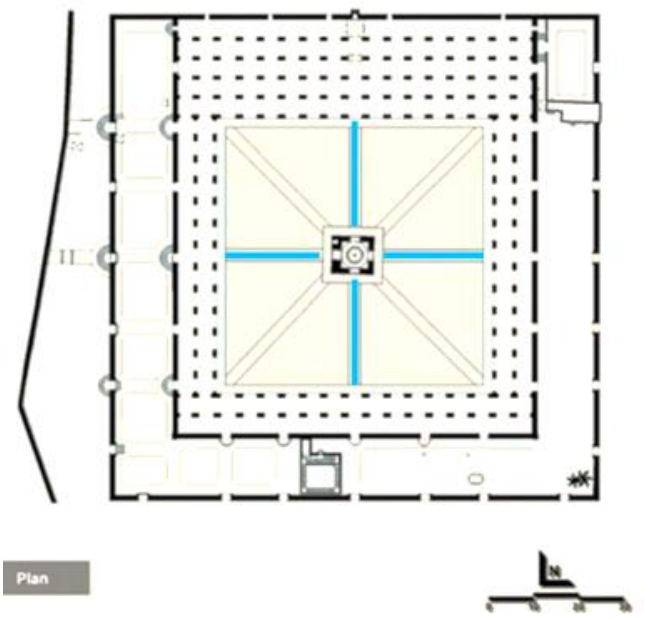

Fig.17. Ibn Tulun Mosque is an example of architectural translation for paradise landscape (Tanglay,2004) With its four rivers
There are fourmain madhahib of Sunni Islam: Maliki, Shafi'I, Hanbali, Hanafi.

Because of that most of madrasas have taken the form of cruciform plan with four Iwans facing a Sahn which sometimes has a central fountain.

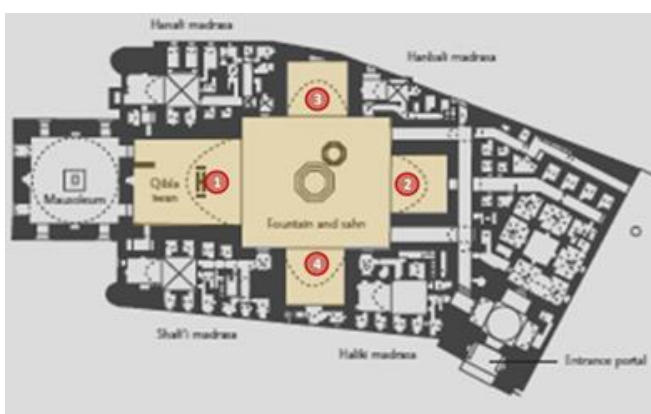

Fig.18 Plan of Madrasa of Sultan Hassan

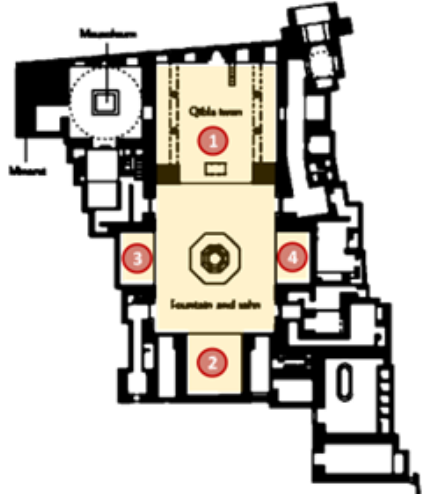

Fig.19 Plan of the Khanqah-Madrasa of Al-Zahir Barquq.

\subsection{Number five in Islamic architecture:}

There are five pillars of religion; five Devine Presences; five fundamental dogmas; five actions; and five daily times of prayer.

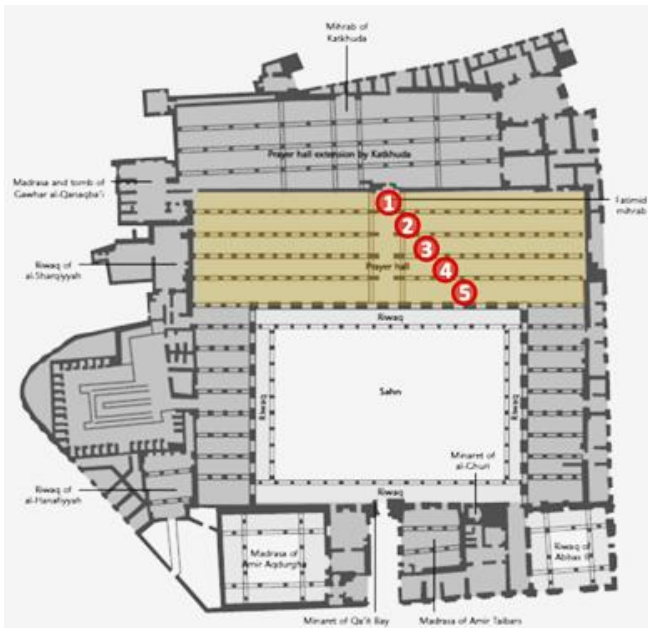

Fig.20 The original mosque of al-Azhar with a prayer hall five aisles deep facing a sahn

5.4 Number seven in Islamic architecture: 
The perfect number is seven. In Islamic tradition there are references to seven: - Seven heavens: The miraj or Ascension story of the Prophet Muhammad (d. 632 C.E.), the Prophet of Islam, is of particular importance in reference to the miraculous nature of the number seven. According to Muslim tradition, the Prophet Muhammad ascended into the seven heavens during his lifetime in Jerusalem, either physically or spiritually, and came into direct contact with the divine (Sahibzada, 2009).

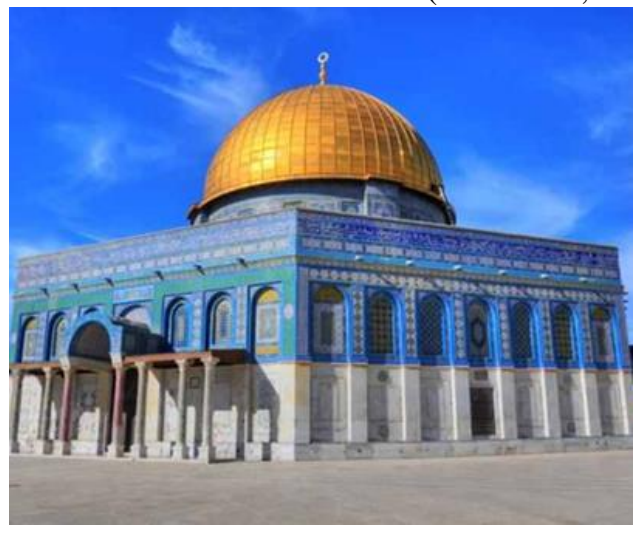

Fig.21 The Dome of the Rock, a commemorative octagon building

Divided into seven separate panels

5.5 Number eight in Islamic architecture: According to Quran verse,

$$
\begin{gathered}
\text { (و الملك علي آرجائها ويحمل عرش ربك فوقهم يومئذ ثمانية) } \\
\text { Surat Al Haqah, Verse } 17
\end{gathered}
$$

God's throne is carried by eight angels. The reflections of that in Islamic architecture in Cairo may be found in: Octagon shape of Fawara, eight columns which support the dome, dome base or drum in its octagonal form, octagonal timber frame from which hang mosque lamps, eight-pointed stars, ect.

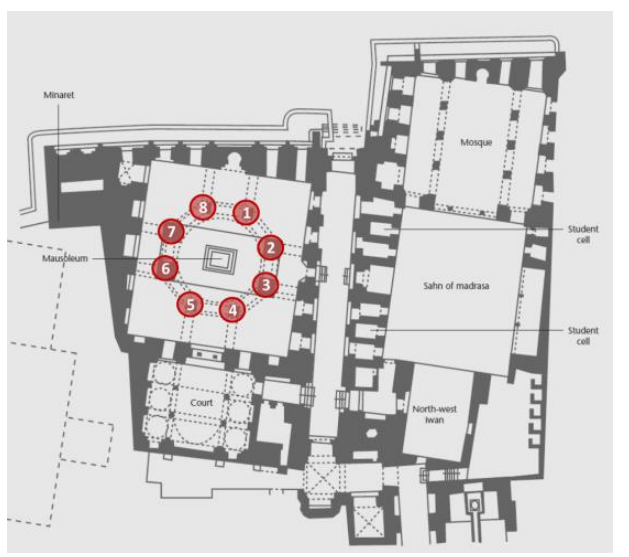

Fig.22 Plan of madrasa and mausoleum of Sultan Qala'un .There are 4 granite columns and4 piers supporting the octagonal base of mausoleum dome 6. Conclusion:
Numbers have constant values but on the other hand several numbers held symbolic significance and have played symbolic roles in Egyptian sacred art and architecture.

The research discussed various examples of numbers and their symbolism but there are other numbers having symbolism that is reflected on sacred buildings and the previous list of sacred numbers is by no means complete. It gives an impression as to how numbers were perceived in different religions and reflected on religious architecture.

The civilization of ancient Egypt was symbolically oriented to a degree rarely equaled by other cultures. It was through symbols that the Egyptians represented and affirmed many of their ideas, beliefs and attitudes regarding the nature of life, death, the supernatural and reality. Several numbers held symbolic significance for Ancient Egyptians and numbers have played symbolic roles in Egyptian sacred architecture

Coptic architecture is rich with symbolism for the reason that there are some issues such as the nature of God and the Trinity, hard to be explained in words but could be expressed symbolically.

Islamic architecture has used symbolism in different tools such as color symbolism, number symbolism and form symbolism to reach the spiritual atmosphere in sacred buildings.

The research conclude that numbers represent more than quantities, they also have qualities which may differ between cultures or religions.

\section{References:}

[1] Watson J.," Ancient Egyptian Symbolism, an Introduction", American University in Cairo, 2002.

[2] Bauval R., The Egypt Code, The Disinformation co. Ltd., 2010.

[3] Bruno, J., And Now There is Light, 2006.

[4] Cerny J., Ancient Egyptian Religion, Hutchinson's University Library, 1952.

[5] Ernest A., Egyptian Religion: Egyptian Ideas of the Future Life, Cosimo Classics, 2010

[6] Gamal Hermina, An approach to Coptic Architecture, 2006.

[7] Kamil J., Christianity in the Land of the Pharaohs: The Coptic Orthodox Church. Cairo: American University in Cairo, 2002.

[8] Lawlor R., Sacred Geometry: Philosophy \& Practice, 2002.

[9] Lehman H., The Language of God in the Universe, Pillar Ministry, USA, 2006.

[10]Leonard H., Religion in Ancient Egypt: Gods, Myths, and Personal Practice, Cornell University Press, 1991. 
[11] Mehnaz Sahibzada, The Symbolism Of The Number Seven In Islamic Culture And Rituals,Thomson,2009.

[12]Pinch G., Egyptian Mythology: A Guide to the Gods, Goddesses, and Traditions, Oxford University Press, 2004.

[13] Rawlinson, History of Ancient Egypt, Biblio Bazaar, 2009.

[14] Seriany Y., Coptic art: Sculpture, Architecture, AnpaRowais, 1995.

[15] Sarkis Shahinian, Armenien: Tagebucheiner Reise in das Land des Ararat, 1996.

[16] Schimmel A., The Mystery of Numbers, Oxford University Press, 1994.

[17] Sill G., A handbook of symbols in Christian art, Cassell, London, 1976.

[18] Shahinian S., Armenien: Tagebucheiner Reise in das Land des Ararat, vdf Hochschulverlag AG, 1996.

[19] TanglayO., "Reflections of paradise in Islamic Architecture", 2004.

[20] http://hubpages.com/hub/numbers

[21] http://www.ancientegyptonline.co.uk

[22] http://www.starsurfin.com/stars.htm

[23] http://www.egyptianmyths.net/star.htm

[24] http://www.kingtutone.com/ancient-egypt/ba-ka/

[25] http://www.thekeep.org/ kunoichi/kunoichi/the mestream/nun.html

[26] http://www.globalegyptianmuseum.org 